\title{
Clinical Experiences with Febrile Infants, Younger than Three Months, with Urinary Tract Infection in a Single Center for Four Years : Incidence, Pathogens and Viral Co-infections
}

\author{
Seok Ho Yoon, M.D. \\ Son Moon Shin, M.D., Ph.D. \\ Sung Won Park, M.D, Ph.D. \\ Cheil General Hospital \&Women's \\ Health Care Center Dankook University \\ College of Medicine Seoul, Korea
}

\section{Corresponding author: \\ Sung Won Park, M.D., Ph.D. \\ Department of Pediatrics, Cheil General \\ Hospital and Woman's Health Care Center, \\ Dankook University College of Medicine, \\ 17, Seoae ro 1 Gil, Jung gu, Seoul 04619 \\ Republic of Korea \\ Tel: +82-2-2000-7169 \\ Fax: +82-2-2000-7778 \\ E-mail:swped@naver.com}

Received: 1 September 2017

Revised: 21 September 2017

Accepted: 27 September 2017
Purpose: The aim of this study was to analyze the incidence and microbiological characteristics of urinary tract infection in infants aged younger three months and to compare with other infection with positive urine culture.

Methods: We retrospectively reviewed the medical records of 425 infants with a tympanic temperature $>37.6^{\circ} \mathrm{C}$, aged younger than three months, who were admitted to Cheil General Hospital in Seoul, Korea, from January 2013 to December 2016. Demographic and clinical features, laboratory findings, respiratory virus PCR and the pathogens of a urine culture were analyzed.

Results: A total of 88 infants ( 63 males, 25 females) had urinary pathogens detected in the urine culture test. The incidence of UTI in febrile infants aged younger 3 months was $11 \%$. The most common pathogen which causes UTI was $E$. coli as same as in previous studies. They were divided into a UTI group $(n=48)$ and a nonUTI group ( $n=40)$. In comparison of both group, leukocytosis, $C$-reactive protein level, Absolute neutrophil count level, peak temperature is statistically significant. In both group, there were co-infections with viral pathogens in some cases, and the odd ratio of non-UTI group with viral infection was 3.28.

Conclusion: The study determined the incidence and pathogen of UTI in febrile infants, aged younger three months. E. coli was responsible for the majority UTI. There were some viral co-infections in febrile infants with bacteriuria and incidence was higher in non-UTI group. WBC count, ANC count and CRP level were the differentiating factors of UTI from non-UTI group.

Key words: Young infants, Urinary tract infection, Urinary pathogen, Virus infection

\section{Introduction}

Fever is the most common major symptom in infants aged younger than 3 months who visit the emergency department or outpatient clinic. Causes of fever in these infants range from mild viral infections (which are usually selflimiting) to serious bacterial infections, such as urinary tract infections (UTIs), bacteremia, and bacterial meningitis, which are progressive and lead to permanent neurological sequelae or death without proper antibiotic treatment ${ }^{1-3)}$. UTIs, in particular, are among the most common bacterial infections in children. The incidence of UTI is $3 \%$ to $4.6 \%$ in neonates, $0.7 \%$ to $5.9 \%$ 
in infants aged up to 1 year, $1 \%$ to $3 \%$ in children aged 1 to 5 years, and $0.71 \%$ to $2.3 \%$ in children of school age ${ }^{4,5)}$. Approximately $7 \%$ to $8 \%$ of girls and $2 \%$ of boys will develop a UTI during the first 8 years of life ${ }^{6}$. The most common pathogen is Escherichia coli, which causes up to $70 \%$ to 90 $\%$ of all UTIs ${ }^{7,8)}$.

In infants with UTI who are younger than 3 months of age, symptoms such as fever, vomiting, and a refusal to eat are nonspecific, and may result in delayed diagnosis and major complications, such as renal scarring. Therefore, accurate diagnosis and early appropriate treatment in this age group are important ${ }^{9,10}$. The purpose of this study was to analyze the incidence and microbiological characteristics of UTIs in infants aged younger than 3 months, and to compare these findings with a non-UTI group, for example, a group with viral infection and bacteriuria.

\section{Materials and methods}

We retrospectively reviewed the medical records of 425 infants aged younger than 3 months ( $<90$ days), with a tympanic temperature $>37.6^{\circ} \mathrm{C}$, who were admitted to Cheil General Hospital \& Women's Healthcare Center at Dankook University College of Medicine in Seoul, Korea, from January 2013 to December 2016. Demographic and clinical features, laboratory findings, respiratory virus polymerase chain reaction (PCR), rapid stool antigen test results, and the pathogens found on urine culture were analyzed. This study was approved by the Institutional Review Board and Research Ethics Committee of the Cheil General Hospital and Women's Healthcare Center (IRB No.CGH-IRB-201738).

Urine samples were collected using a bag after sterilizing the genital area with chlorhexidine gluconate solution 0.25 $\mathrm{mL} / \mathrm{mL}$. Following sterilization, a sterile urine bag was gently attached to the area using adhesive strips, and urinalysis was completed as soon as possible after voiding. A UTI was diagnosed if the urinalysis result was positive, the patient was symptomatic, and a single organism was cultured with $>50,000$ colony forming units $(\mathrm{CFU}) / \mathrm{mL}^{11)}$. Additionally, if the count in the urine culture was more than $50,000 \mathrm{CFU} / \mathrm{mL}$ without a positive urinalysis, and if the renal ultrasound or $99 \mathrm{~m}$-technetium dimercaptosuccinic acid (99mTc-DMSA) scan showed positive signs of infection such as scarring, we also diagnosed a UTI. In contrast, if the renal ultrasound and 99m Tc-DMSA scan were normal, we diagnosed an infection with associated bacteriuria, defined as a pseudo-UTI. We defined pyuria in the urine as a white blood cell count $>5$ per high power field on urine microscopic examination. Positive signs of infection on renal ultrasound included increased echogenicity or swelling in the renal parenchyma. Furthermore, an abnormal DMSA renal scan was indicated by decreased uptake in single or multiple lesions or by diffuse uptake, and by a change in renal size.

Fever was defined as an ear (tympanic membrane) temperature above $37.6^{\circ} \mathrm{C}$. Age at diagnosis, sex, white blood cell (WBC) count, absolute neutrophil count (ANC), lymphocytes, platelet count, C-reactive protein (CRP) level, serum electrolytes (sodium, potassium, and chloride, total carbon dioxide $\left[\mathrm{tCO}_{2}\right]$, renal function tests (blood urea nitrogen and creatinine), and peak degree of fever were compared between infants with and without UTI (Fig. 1).

Multiplex reverse transcription-PCR analysis of nasopharyngeal aspirates for respiratory viruses was performed. The kit enabled simultaneous detection of influenza A virus, influenza $B$ virus, human respiratory syncytial virus A, human respiratory syncytial virus $B$, human adenovirus, human metapneumovirus, human coronavirus, human

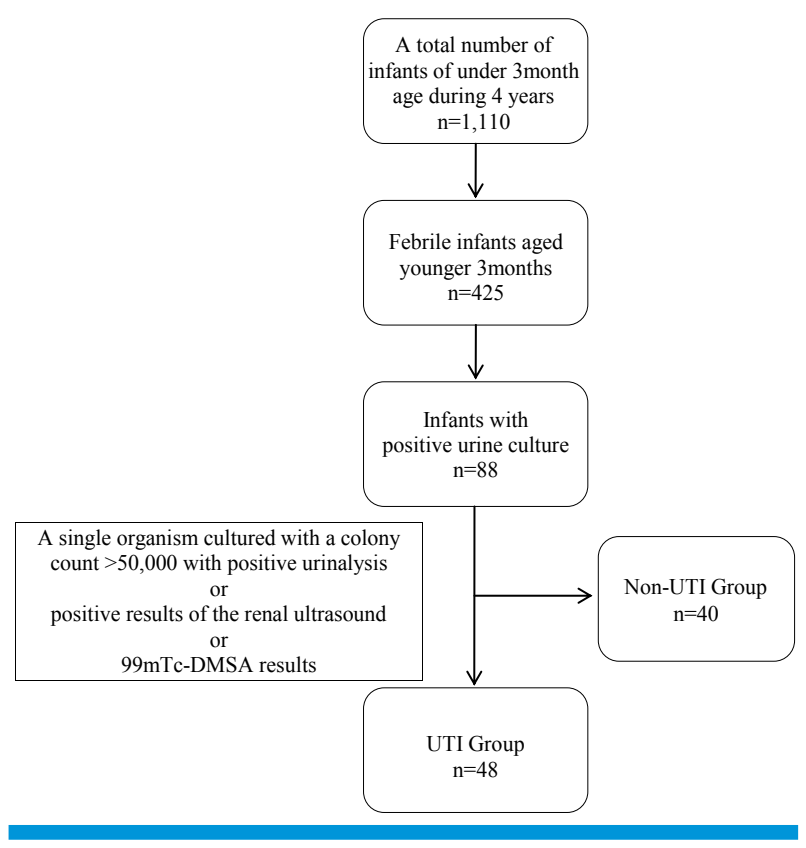

Fig.1. Flow diagram to classify the UTI group and Non-UTI group. 
parainfluenza virus, human rhinovirus, and human bocavirus.

Statistical analysis was performed using IBM $^{\circledR}$ SPSS $^{\circledR}$ Statistics ver. 22.0 (IBM Corp., Armonk, NY, USA) and a $P$ value of less than 0.05 was considered statistically significant. Continuous variables were expressed as mean \pm standard deviation (SD) and were compared between the groups using bivariate logistic regression analysis.

\section{Results}

A total of 425 infants (229 male, 196 female) were included in this study. A total of 88 infants (63 male, 25 female) had urinary pathogens detected in the urine culture test. E. coli was the most frequent pathogen and was detected in 45 cases, followed by Enterobacter (in 18 cases) and Klebsiella (in 10 cases) (Table 1 ).

The 88 cases positive for a urine pathogen were classified into either a UTI or non-UTI group, based on our study criteria. A total of 36 patients had a UTI with a single pathogen and more than $100,000 \mathrm{CFU} / \mathrm{mL}, 2$ had a single pathogen and more than $50,000 \mathrm{CFU} / \mathrm{mL}$ and a positive urinalysis, and 1 had a single pathogen and more than $50,000 \mathrm{CFU} / \mathrm{mL}$ and a positive imaging study. In the latter case, both the renal ultrasound and DMSA renal scan showed positive signs of infection. Nine patients had a single pathogen and more than $50,000 \mathrm{CFU} / \mathrm{mL}$ and a positive urinalysis and imaging study (Table 2).

Table 1. Types of Pathogens detected in Urine Cultures

\begin{tabular}{lc}
\hline Pathogens & $\mathrm{n}$ \\
\hline Escherichia coli & 45 \\
Enterobacter & 18 \\
Klebsiella & 10 \\
Enterococcus & 7 \\
Staphylococcus aureus (MRSA) & 2 \\
Streptococcus anginosus & 1 \\
Pseudomonas aeruginosa & 1 \\
Streptococcus agalactiae (GBS) & 1 \\
Kocuria kristinae & 1 \\
Citrobacter koseri & 1 \\
Staphylococcus epidermidis & 1 \\
Total & 88 \\
\hline
\end{tabular}

Abbreviations: GBS, Group B-Streptococcus; MRSA, methicillin-resistant Staphylococcus aureus.
The UTI group included 48 infants (41 male, 7 female). Ages ranged from 11 to 99 days, with a mean age of $54.9 \pm$ 23.1 days. Ten were less than 28 days old (20.8\%). Most patients in the UTI group visited the hospital with a fever of $38.5^{\circ} \mathrm{C}$ or higher. Pyuria at admission was found in 37 patients (77.1\%), but only 14 (29.2\%) were nitrazine-positive. We performed a tap for cerebrospinal fluid in 14 severely ill infants aged less than 28 days (29.2\% of the UTI group) (Table 3). E. coli was the most common cause of UTI (35 cases), followed by Enterobacter cloacae and Klebsiella pneumoniae, in that order (Table 4).

Table 2. Classification UTI with non-UTI Group with Positive Urine Culture

\begin{tabular}{lrc}
\hline Features & UTI & non-UTI \\
\hline More than 100,000 pathogens & 36 & 0 \\
50,000-100,000 pathogens with positive urinalysis & 2 & 0 \\
50,000-100,000 pathogens with positive image study & 1 & 0 \\
50,000-100,000 pathogens with both above features & 9 & 0 \\
50,000-100,000 pathogens without both above features & 0 & 9 \\
Under 50,000 pathogens with positive urinalysis & 0 & 4 \\
Under 50,000 pathogens with positive image study & 0 & 0 \\
Under 50,000 pathogens with negative urinalysis & 0 & 27 \\
Total & 48 & 40 \\
\hline
\end{tabular}

Abbreviations: UTI, urinary tract infection.

Table 3. Characteristics of UTI Patients

\begin{tabular}{|c|c|c|}
\hline Variables & Data & Range \\
\hline Age (days) & $54.9 \pm 23.1$ & $(11-90)$ \\
\hline$\leq 28 \mathrm{~d}$ old & $\mathrm{n}=10(20.8 \%)$ & \\
\hline Sex (M:F) & $41: 7$ & \\
\hline Gestational age (Wks) & $38.0 \pm 6.0$ & $(31+6-41+5)$ \\
\hline Birth weight (gm) & $3,204.0 \pm 633.0$ & $(1,025-4,225)$ \\
\hline Having Siblings & $16(33.3 \%)$ & \\
\hline Highest body temperature $\left({ }^{\circ} \mathrm{C}\right)$ & $38.5 \pm 0.6$ & $(37.6-40.2)$ \\
\hline Hospital days (days) & $4.0 \pm 1.0$ & $(3-6)$ \\
\hline $\mathrm{WBC}\left(\times 10^{3} / \mathrm{uL}\right)$ & $13.62 \pm 5.21$ & $(3.85-28.63)$ \\
\hline Seg. Neutrophil (\%) & $45.75 \pm 16.95$ & $(6-75)$ \\
\hline CRP (mg/dL) & $3.52 \pm 4.43$ & $(0.1-23.6)$ \\
\hline TCO2 (mmol/L) & $21.3 \pm 2.3$ & $(14.5-27.0)$ \\
\hline Respiratory Virus PCR performed & $43(89.5 \%)$ & \\
\hline Pyuria & 37 (77.1\%) & \\
\hline Nitrazine & $14(29.2 \%)$ & \\
\hline Lumbar puncture done & $14(29.2 \%)$ & \\
\hline Imaging studies & $45(93.8 \%)$ & \\
\hline
\end{tabular}

Data was shown as mean \pm standard deviation.

Abbreviations: UTI, urinary tract infection; WBC, white blood cell count; CRP, C-reactive protein concentration; TCO2, total carbon dioxide. 
Most febrile infants aged less than 3 months undergo respiratory virus PCR and rapid stool antigen testing, if approved by the parents. Of 48 UTI patients, 43 underwent a viral study. Of these, 14 were found to have an associated viral infection. Rhinovirus was most common, followed by respiratory syncytial virus and influenza virus. Some cases were infected with more than 2 viruses. Of the 40 non-UTI cases, 38 underwent testing. Viruses were detected in 23 cases, with the most common being rotavirus. The odds ratio (OR) for a non-UTI in a viral infection subgroup was 3.28 (Table 5).

Laboratory test results were compared between the UTI and non-UTI groups. Among various factors, WBC count (mean value: $13,620 \pm 5,210 / \mu \mathrm{L}$ vs. $10,280 \pm 4,630 / \mu \mathrm{L} ; P<0.002$ ), ANC count (mean value: $6,406 \pm 4,047$ vs $4,042 \pm 3,007 ; P<$ 0.002 ), CRP (mean value: $3.52 \pm 4.43 \mathrm{mg} / \mathrm{dL}$ vs $0.76 \pm 1.38$ $\mathrm{mg} / \mathrm{dL} ; P<0.001$ ), and peak temperature (mean value: $38.5 \pm$ $0.6^{\circ} \mathrm{C}$ vs. $\left.38.2 \pm 0.3^{\circ} \mathrm{C} ; P<0.005\right)$ were significantly different between the 2 groups (Table 6). There were no significant differences in other factors.

Table 4. Types of Pathogens of UTI Group

\begin{tabular}{lc}
\hline Pathogens & $\mathrm{n}$ \\
\hline Escherichia coli & 35 \\
Enterobacter & 7 \\
Klebsiella & 5 \\
Enterococcus & 1 \\
Total & 48 \\
\hline
\end{tabular}

Abbreviations: UTI, urinary tract infection.

Table 5. Virus Infection with Positive Urine Culture

\begin{tabular}{lccc}
\hline Pathogen & UTI & non-UTI & Sum \\
\hline Rhinovirus & 4 & 2 & 6 \\
Influenza A & 2 & 4 & 6 \\
Influenza B & 1 & 1 & 2 \\
RSV & 2 & 4 & 6 \\
Parainfluenza & 1 & 4 & 5 \\
RSV+Rhinovirus & 1 & 0 & 1 \\
Bocavirus & 1 & 0 & 1 \\
Bocavirus+Rhinovirus & 1 & 0 & 1 \\
Adenovirus & 1 & 0 & 1 \\
Bocavirus+Adenovirus & 0 & 1 & 1 \\
Metapneumovirus & 0 & 1 & 1 \\
Rotavirus & 0 & 6 & 6 \\
Total & 14 & 23 & 37 \\
\hline
\end{tabular}

Abbreviations: UTI, urinary tract infection; RSV, Respiratory syncytial virus.

\section{Discussion}

UTI is the most common bacterial infection in febrile infants aged younger than 3 months, with a reported prevalence of about $7 \%{ }^{12}$. Accurate diagnosis is important to ensure timely treatment of UTI, while avoiding the use of unnecessary antibiotics in cases in which UTI is unlikely. Traditionally, urine culture has been the reference standard for the diagnosis of UTI. In general, urine analysis using bags is useful and easy for screening, but the false-positive rates associated with this method are unacceptably high. Furthermore, the presence of infection is difficult to determine when microscopic examination reports are equivocal with respect to the number of $\mathrm{WBCs}^{13)}$. Therefore, a variety of criteria and tests have been proposed to predict UTI and complications ${ }^{14}$.

Concomitant bacteremia is associated with UTI in young infants, and many studies have focused on the early identification of predictors of severe bacterial infection in this age group ${ }^{15)}$. During the late 1980s and early 1990s, new criteria were developed to distinguish low-risk and highrisk infants, and recommended close observation without antibiotic treatment for the management of UTI in this age group. Various low-risk criteria were proposed and their utility has been validated ${ }^{16)}$. There are few data regarding UTIs in infants younger than 3 months of age. Thus, the major purpose of our retrospective study was to analyze the incidence and microbiological aspects of the first episodes of UTI in infants younger than 3 months of age, and to compare them with uninfected infants with positive urine cultures.

Anbar et al. reported that severe bacterial infections affected $10 \%$ of febrile infants younger than 3 months of age ${ }^{17)}$. In this study, the UTI incidence was $11 \%$ among febrile

Table 6. Comparison UTI Group with non-UTI Group with Positive Urine Culture

\begin{tabular}{lcccc}
\hline & $\begin{array}{c}\text { WBC } \\
\left(\times 10^{3} / \mathrm{uL}\right)\end{array}$ & ANC & $\begin{array}{c}\text { CRP } \\
(\mathrm{mg} / \mathrm{dL})\end{array}$ & $\begin{array}{c}\text { Peak-BT } \\
\left({ }^{\circ} \mathrm{C}\right)\end{array}$ \\
\hline UTI group & $13.62 \pm 5.21$ & $6,406 \pm 4,047$ & $3.52 \pm 4.43$ & $38.5 \pm 0.6$ \\
non-UTI group & $10.28 \pm 4.63$ & $4,042 \pm 3,007$ & $0.76 \pm 1.38$ & $38.2 \pm 0.3$ \\
$P$-value & $0.002^{*}$ & $0.002^{*}$ & $0.001^{*}$ & $0.005^{*}$ \\
\hline
\end{tabular}

Data was shown as mean \pm standard deviation. ${ }^{*} P<0.05$.

Abbreviations: UTI, urinary tract infection; WBC, white blood cell count; ANC, absolute neutrophil count; CRP, C-reactive protein concentration; $\mathrm{BT}$, body temperature. 
infants under 3 months of age. E. coli was responsible for the majority of UTIs. Our data are similar to those previously published showing $E$. coli involvement in $60 \%$ to $89 \%$ of first UTI episodes ${ }^{18}$. The current guidelines for the treatment of neonatal UTI take these findings into consideration, but may often be inappropriate for evaluating hospitalized infants with non-E. coli UTI, which is generally caused by pathogens resistant to antibiotics and is therefore more difficult to treat ${ }^{19)}$.

Some studies have suggested that there is a significantly lower prevalence of UTI in infants with viral infections or bronchiolitis $^{20,21)}$. In this study, 29\% of infants with UTI showed positive findings for respiratory virus. This is a relatively high percentage in comparison with that in previous studies. It can be assumed that the high coinfection rate with respiratory virus is due to decreased immunity, and that infants younger than 3 months of age with a UTI should be evaluated for a viral infection accompanying the UTI if fever does not subside in response to appropriate antibiotic treatment.

There were 23 viral infections in the non-UTI group with bacteriuria in this study (OR: 3.28). This suggests that the viral infection incidence could be higher in febrile infants with bacteriuria who were not diagnosed with UTI. Almost all of the febrile infants in this study underwent viral testing. Notably, the results of urine cultures obtained using bag samples has a high false-positive rate, and pathogen growth requires time. Therefore, if the clinical course of an infant with a UTI is unusual, a viral study can be helpful in predicting the clinical course and outcome.

Finally, the definition of UTI is a common limitation in studies assessing the performance of urinalysis. We used a colony count definition, with a bacterial concentration of $\geq 50,000 \mathrm{CFU} / \mathrm{mL}$ in a voided urine bag to indicate UTI. In the 2011 updated American Academy of Pediatrics guidelines, the definition of UTI was updated to include both a positive urine culture with $\geq 50,000 \mathrm{CFU} / \mathrm{mL}$ of a single urinary pathogen, and a positive urinalysis with pyuria and/or bacteriuria from a specimen obtained by catheterization $^{22)}$. However, in practice, catheterization in young infants is not easy and the use of a sterile urine bag is believed to be the most noninvasive method. Therefore, obtaining a colony count is important in the diagnosis of UTI with sterile urine bag urinalysis, and supporting evidence, such as the presence of positive imaging findings, is also important. And comparing the laboratory results such as WBC, ANC and CRP can be helpful to distinguish falsepositive results from UTIs.

Nevertheless, a major limitation in our study is that urine was collected with a sterile urine bag. Lee reported a $50 \%$ to $57 \%$ false-positive rate with the urine bag method in Korea $^{23)}$. Bladder puncture or catheterization shows more accurate results, but both are too invasive to perform in infants. Thus, clinicians must develop a new method to collect urine samples from infants. The development of a better method may also simplify the diagnosis of UTI in infants.

\section{Conflicts of interest}

No potential conflict of interest relevant to this article was reported.

\section{References}

1. Nelson DS, Walsh K, Fleisher GR. Spectrum and frequency of pediatric illness presenting to a general community hospital emergency department. Pediatrics 1992;90:5-10.

2. Baraff LJ, Bass JW, Fleisher GR, Klein JO, McCracken GH Jr, Powell $\mathrm{KR}$, Schriger DL. Practice guideline for the management of infants and children 0 to 36 months of age with fever without source. Ann Emerg Med 1993;22:1198-210.

3. Luszczak M. Evaluation and management of infants and young children with fever. Am Fam Physician 2001;64:1219-26.

4. Hoberman A, Chao HP, Keller DM, Hickey R, Davis HW, Ellis D. Prevalence of urinary tract infection in febrile infants. J Pediatr 1993;123:17-23.

5. Miron D, Shatzberg G, Landau D, Halevy R. Treatment of community-acquired urinary tract infections. Israel J Pediatr 2001;38: 7-15.

6. Israeli Central Bureau of Statistics, Statistical Abstracts of Israel, 2005-2009, Data on Beer-Sheva sub-district population.

7. Ismaili K, Lolin K, Damry N, Alexander M, Lepage P, Hall M. Febrile urinary tract infections in 0- to 3-month-old infants: a prospective follow-up study. J Pediatr 2011;158:91-4.

8. Roberts KB, Charney E, Sweren RJ, Ahonkhai VI, Bergman DA, Coulter MP, et al. Urinary tract infection in infants with unexplained fever: a collaborative study. J Pediatr 1983;103:864-7.

9. Merrick MV, Notghi A, Chalmers N, Wilkinson AG, Uttley WS. Long-term follow up to determine the prognostic value of imaging after urinary tract infections. Part 2: Scarring. Arch Dis Child 1995;72(5):393-6. 
10. Rushton HG. Urinary tract infections in children. Epidemiology, evaluation, and management. Pediatr Clin North Am 1997;44(5): 1133-69.

11. Urinary Tract Infection : Clinical Practice Guideline for the Diagnosis and Management of the initial UTI in Febrile Infants and Children 2 to 24 Months, Subcommittee on Urinary Tract Infection, Steering Committee on Quality Improvement and Management. Pediatrics 2011;128:595-607.

12. Shaikh N, Morone NE, Bost JE, Farrell MH. Prevalence of urinary tract infection in childhood: A meta-analysis. The Pediatric Infectious Disease Journal 2008;27:302-8.

13. Liaw LC, Nayar DM, Pedler SJ, Coulthard MG. Home collection of urine for culture from infants by three methods: survey of parents' preferences and bacterial contamination rates. BMJ 2000; 320(7245):1312-3.

14. Kang MJ, Shin HK, Yim HE, Je BK, Eun SH, Choi BM, et al. Urinary tract infections in infants under six months of age. Korean J Pediatr 2006;49(3):278-86.

15. Manucha V, Rusia U, Sikka M, Faridi MM, Madan N. Utility of haematological parameters and C-reactive protein in the detection of neonatal sepsis. J Paediatr Child Health 2002;38(5):459-64.

16. Dagan R, Powell KR, Hall CB, Menegus MA. Identification of infants unlikely to have serious bacterial infection although hospitalized for suspected sepsis. The Journal of Pediatrics 1985;107 (6):855-60.
17. Anbar RD, Richardson-de Corral V, O'Malley PJ. Difficulties in universal application of criteria identifying infants at low risk for serious bacterial infection. J Pediatr 1986;109(3):483-5.

18. Roberts KB. Urinary tract infection treatment and evaluation. Update Pediatr Infect Dis J 2004;23:1163-4.

19. Marcus N, Ashkenazi S, Yaari A, Samra Z, Livni G. Non-Escherichia coli versus Escherichia coli community-acquired urinary tract infection in children hospitalized in a tertiary center-relative frequency, risk factors, antimicrobial resistance and outcome. Pediatr Infect Dis J 2005;24:581-5.

20. Byington CL, Enriquez FR, Hoff C, Tuohy R, Taggart EW, Hillyard $D R$, et al. Serious bacterial infections in febrile infants 1 to 90 days old with and without viral infections. Pediatrics 2004;113(6): 1662-6.

21. Zorc JJ, Levine DA, Platt SL, Dayan PS, Macias CG, Krief W, et al. Clinical and demographic factors associated with urinary tract infection in young febrile infants. Pediatrics 2005;116(3): 644-8.

22. Roberts KB, Subcommittee on Urinary Tract Infection, Steering Committee on Quality Improvement and Management. Urinary tract infection: clinical practice guideline for the diagnosis and management of the initial UTI in febrile infants and children 2 to 24 months. Pediatrics 2011;128(3):595-610.

23. Lee SJ, Guidelines for childhood urinary tract infection. Korean J Pediatr 2009;52:976-83. 